\title{
Differences between infected and noninfected patients with acute alcoholic hepatitis
}

GY MINUK, MD, A COHEN, V THOMPSON

GY Minuk, A Cohen, V Thompson. Differences between infected and noninfected patients with acute alcoholic hepatitis. Can $J$ Infect Dis 1992;3(5):240-242. The medical records of 97 patients with alcoholic hepatitis, including 20 with coexisting bacterial infections and 77 with no evidence of bacterial infection, were reviewed to determine whether commonly employed tests would be useful in distinguishing between the two groups. The results of the study revealed that patients with alcoholic hepatitis and bacterial infections had higher temperatures $\left(38.4 \pm 0.9^{\circ} \mathrm{C}\right.$ versus $\left.37.9 \pm 0.7^{\circ} \mathrm{C}, \mathrm{P}<0.05\right)$ and white blood cell counts ( $16.4 \pm 7.9$ versus $\left.11.2 \pm 6.4 \times 10^{9} / \mathrm{L}, \mathrm{P}<0.005\right)$, but lower serum bilirubin levels $(39 \pm 42$ versus $115 \pm 152$, $\mathrm{P}<0.05$ ), than patients with alcoholic hepatitis alone. Patients with alcoholic hepatitis and bacterial infections also tended to reach maximum temperatures and white blood cell counts later in their hospital stay than patients with alcoholic hepatitis alone ( $5.1 \pm 5.3$ versus $2.5 \pm 1.8$ days, and $7.7 \pm 11.8$ versus $4.4 \pm 5.7$ days, respectively, $\mathrm{P}<0.05$ and $\mathrm{P}<0.005$ ). These results suggest that the extent and timing of peak abnormalities in body temperature, white blood cell count and serum bilirubin level may be of value in distinguishing patients with alcoholic hepatitis with bacterial infections from patients with alcoholic hepatitis alone.

Key Words: Alcoholic hepatitis, Bilirubin, Fever, Leukocytosis, Liver

\section{Patients porteurs d'hépatite alcoolique aiguë et atteints ou non d'infections bactériennes}

RÉSUMÉ: On a étudié le dossier de 97 patients atteints d’hépatite alcoolique, parmi lesquels se trouvaient 20 cas d'infections bactériennes coexistantes et 77 cas qui en semblaient exempts, afin de déterminer si les examens couramment utilisés pouvaient servir à différencier les deux groupes. Les résultats révèlent une température corporelle et une leucocytémie plus êlevées chez les patients souffrant d'hépatite alcoolique et d'infections bactériennes $\left(38,4 \pm 0,9^{\circ} \mathrm{C}\right.$ comparés à $37,9 \pm 0,7^{\circ} \mathrm{C}, \mathrm{P}<0,05$; et $16,4 \pm 7,9 \times 10^{9} / \mathrm{L}$ comparés à $11,2 \pm 6,4 \times 10^{9} / \mathrm{L}, \mathrm{P}<0,005$, respectivement) mais des concentrations sériques de bilirubine inférieures (39 \pm 42 comparés à $115 \pm 152$, $\mathrm{P}<0,05)$ par rapport aux malades présentant seulement une hépatite alcoolique. Les patients souffrant d'infections bactériennes concomitantes tendaient également à atteindre leurs températures et leucocytose maximales plus tard en cours d'hospitalisation que les patients sans infection $(5,1 \pm 5.3$ comparés à $2,5 \pm 1$. 8 jours, et $7,7 \pm 11,8$ comparés à $4,4 \pm 5,7$ jours, respectivement: $\mathrm{P}<0,05$ et $\mathrm{P}<0,005$ ). Ces résultats suggèrent que l'ampleur et l'horaire des anomalies relatives à la température corporelle, à la leucocytose et au taux de bilirubine de pointes pourraient servir à distinguer les patients atteints d'hépatite alcoolique accompagnée d'infections bactériennes et les patients souffrant seulement d'hépatite alcoolique.

Departments of Medicine and Pharmacology. University of Manitoba: and Health Sciences Clinical Research Centre. Winnipeg. Manitoba

Correspondence and reprints: Dr GY Minuk, Liver Diseases Unit, Health Sciences Centre, 820 Sherbrook Street. Winnipeg. Manitoba R3A 1R9. Telephone (204) 787-4662

Received for publication February 7. 1991. Accepted June 3, 1991 
$\mathrm{F}$ VER AND LEUKOCYTOSIS ARE TWO COMMON FEATURES OF acute alcoholic hepatitis that occur in the absence of infection. It has been estimated that approximately $50 \%$ of patients with alcoholic hepatitis have fever, and $40 \%$ leukocytosis (1). The presence of either finding alone or in combination will often initiate a search to identify a source of infection or, if unsuccessful, an empiric trial of antibiotics. Many of the investigations performed during a 'septic work-up' are invasive and associated with a small but distinct morbidity. Moreover, complications may arise from a course of antibiotics which further adds to patient discomfort and increased health care costs.

To date, there have been few (if any) attempts to determine whether commonly employed tests would be useful in distinguishing patients with alcoholic hepatitis and bacterial infection from patients with alcoholic hepatitis alone. In an attempt to identify such tests, the authors reviewed the medical records of 97 patients, including 20 patients with alcoholic hepatitis in whom culture positive bacterial infections had been documented, and 77 patients with acute alcoholic hepatitis and no clinical, radiological or microbiological evidence of bacterial infection.

\section{PATIENTS AND METHODS}

The selection of patient records for this study has been described in detail elsewhere (2). Briefly, the computer-generated medical records of all patients admitted and discharged from the Health Sciences Centre in Winnipeg, Manitoba between the years 1985 and 1989 with a diagnosis of acute alcoholic hepatitis were reviewed for accuracy of diagnosis and to rule out additional organic disease which might result in fever and leukocytosis, such as cholecystitis or pancreatitis. The charts of these patients were also carefully reviewed to exclude clinical, radiological or microbiological evidence of infection.

The medical records of 26 patients with alcoholic hepatitis and bacterial infection were derived by a similar process, with the exception that the discharge diagnosis included a well documented (culture positive) bacterial infection. Six patients receiving antipyretics and/or corticosteroids were excluded from analysis. The nature of the primary infections in the remaining 20 individuals were bacterial pneumonia in 10 . genitourinary in four, tuberculosis in three, and miscellaneous in three.

The hospital day upon which the variable under consideration reached its maximum degree of abnormality was documented in the two patient populations.

Antibiotic usage was common in both groups, with approximately $5 \%$ of patients having been prescribed at least one antibiotic prior to admission. In the majority of these patients noncompliance was suspected. In addition, all patients with alcoholic hepatitis and infection, and $40 \%$ of patients with alcoholic hepatitis alone, received one to five antibiotics (started empirically on the basis of elevated temperatures and/or white blood cell counts) during their hospital stay. The average duration of antibiotic use was 7.9 days (range one to 33).

\section{STATISTICS}

Two-tailed Student's $t$ test for paired data and Fisher's exact probability test were employed for statistical analyses. A P value less than 0.05 was considered significant. The results represent the mean value \pm standard deviation.

\section{RESULTS}

Table 1 provides the results of all variables analyzed in the two groups. Significant differences were found for three variables; temperature, white blood cell count and serum bilirubin. There were also significant delays to peak temperature recordings $(5.1 \pm 5$. 3 versus $2.5 \pm 1.8$ days, $\mathrm{P}<0.005$ ) and peak white blood cell counts $(7.7 \pm 11.8$ versus $4.4 \pm 5.7$ days, $\mathrm{P}<0.05)$ in patients with alcoholic hepatitis and infection compared to patients with alcoholic hepatitis alone, respectively.

Figure 1 provides individual results for each of the three variables. Ten of 20 patients (50\%) with alcoholic hepatitis and infection had fever (maximum temperatures beyond $38^{\circ} \mathrm{C}$ ) compared to 20 of $53(38 \%)$ with alcoholic hepatitis alone $(\mathrm{P}>0.05)$. White blood cell

TABLE 1

Clinical and laboratory findings in patients with alcoholic hepatitis and bacterial infection versus patients with alcoholic hepatitis alone

\begin{tabular}{|c|c|c|c|c|}
\hline Parameter & Normal range & $\begin{array}{c}\text { Alcoholic hepatitis } \\
(n=77)\end{array}$ & $\begin{array}{l}\text { Alcoholic hepatitis } \\
\text { and infection }(n=20)\end{array}$ & Significance \\
\hline Temperature $\left({ }^{\circ} \mathrm{C}\right)$ & 37.5 & $37.9 \pm 0.7$ & $38.4 \pm 0.9$ & $P=0.03$ \\
\hline White blood cell count $\left(\times 10^{9} / \mathrm{L}\right)$ & 4.5 to 11.0 & $11.2 \pm 6.4$ & $16.4 \pm 7.9$ & $P=0.002$ \\
\hline Alkaline phosphatase (U/L) & 30 to 125 & $228 \pm 151$ & $256 \pm 137$ & NS \\
\hline Aspartate aminotransferase (U/L) & Less than 50 & $252 \pm 203$ & $204 \pm 189$ & NS \\
\hline Total bilirubin ( $\mu \mathrm{mol} / \mathrm{L})$ & 3 to 18 & $115 \pm 152$ & $39 \pm 42$ & $P=0.02$ \\
\hline
\end{tabular}

NS Not significant 


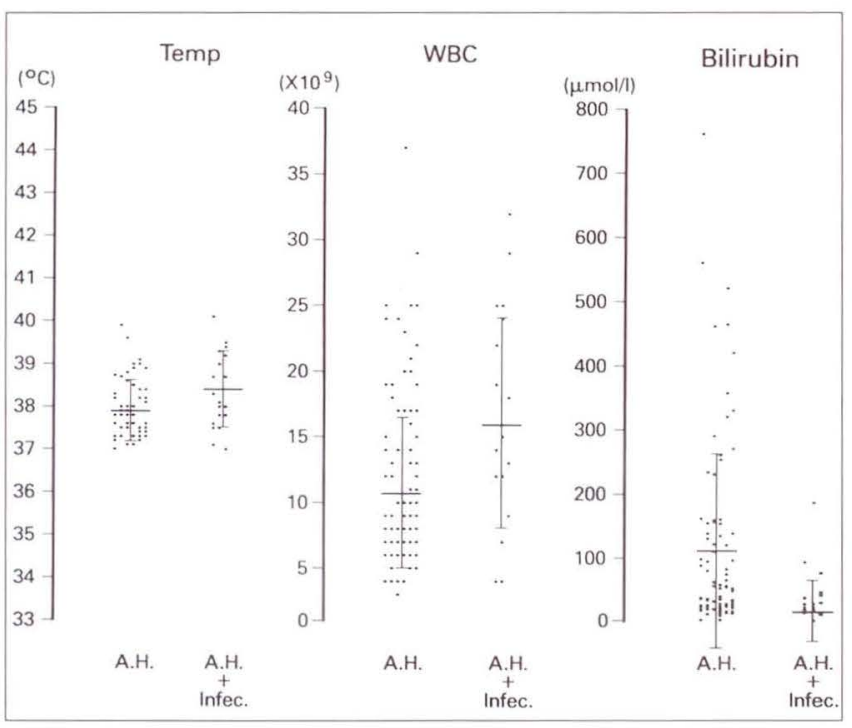

Figure 1) Temperature (Temp), white blood cell count (WBC) and bilirubin levels in patients with alcoholic hepatitis alone (A.H.) and patients with alcoholic hepatitis and superimposed bacterial infection (A.H. + Infec.). Horizontal and vertical bars represent mean $\pm S D$. Differences between the two groups were significant for temperature $(P=0.03)$, white blood cell count $(P=0.002)$ and bilirubin $(P=0.02)$. Normal values for each test are provided in Table 1

counts were elevated in 16 of 20 patients (80\%) with alcoholic hepatitis and infection compared to 30 of 77 patients $(39 \%)$ with alcoholic hepatitis alone $(\mathrm{P}<0.005)$.

\section{DISCUSSION}

The results of this review indicate that fever and leukocytosis are more common and/or elevated in patients with alcoholic hepatitis and infection than in patients with alcoholic hepatitis alone. Unfortunately. the extent of the abnormalities and the degree of overlap between the two groups are such that the tests alone or in combination are not of predictive value in the assessment of individual patients. The significantly lower serum bilirubin levels in patients with alcoholic hepatitis and infection was a somewhat unexpected finding. Given the propensity of bacterial infections to increase serum bilirubin values, one would have predicted higher rather than lower values in these patients (3). It cannot be argued that the presence of infection caused these individuals to seek medical attention earlier in the course of their hepatitis (presumably when bilirubin levels would be lower), as serum aminotransferase values, prothrombin times and albumin levels were either similar or more abnormal in this group than in those without infection. Whether bilirubin levels would stand as a useful predictive indicator in a prospective study of this problem remains to be determined.

The retrospective nature of this review precluded an attempt to determine whether the infections identified in patients with both alcoholic hepatitis and infection occurred prior to or following admission to hospital. Thus, it remains unclear whether the delay in peak white blood cell count and temperature reflects the natural history of infections in alcoholics, or if the majority of bacterial infections in these individuals tend to occur during their hospital stay (4). Nonetheless, the information may be of practical importance in that patients with falling temperatures and/or white blood cell counts during their initial days of hospitalization are less likely to have an underlying infectious process than patients with rising temperatures and leukocytosis.

In summary, the results of this study support the need for physicians to maintain a high degree of vigilance for infections in patients with alcoholic hepatitis. In individual cases, sound clinical judgement and frequent appraisal of the patient's clinical status should remain the ultimate determining factors regarding an empiric trial of antibiotics.

ACKNOWLEDGEMENTS: The authors thank the personnel of the Health Sciences Centre Medical Information Department for their assistance, and Ms D Byron for her prompt and accurate typing of the manuscript. This work was supported by a grant from the Manitoba Medical Service Foundation (MMSF). Dr Minuk is the recipient of an MMSF professorship award.

\section{REFERENCES}

1. Mendenhall CL. Alcoholic hepatitis. In: Schiff L. Schiff ER, eds. Diseases of the Liver, 6th edn. Philadelphia: JB Lippincott Company, 1987:669-85.

2. Minuk GY, Thompson W. Biochemical features of alcohol-induced liver disease in native versus non-native Canadians. Can J Gastroenterol 1990:4:163-6.

3. Klatskin G. Hepatitis associated with systemic infections. In: Schiff L, ed. Diseases of the Liver, 3rd edn. Philadelphia: JB Lippincott Company, 1969:602-44.

4. Ho H, Zukerman MJ, Guerra LG, Pere JF. The role of invasive procedures in the development of nosocomial bacterial peritonitis. Gastroenterology 1991;100:A752. (Abst) 


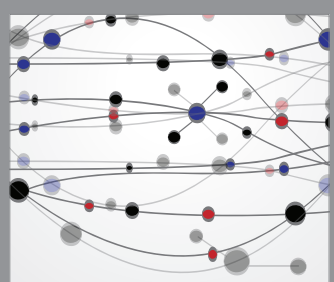

The Scientific World Journal
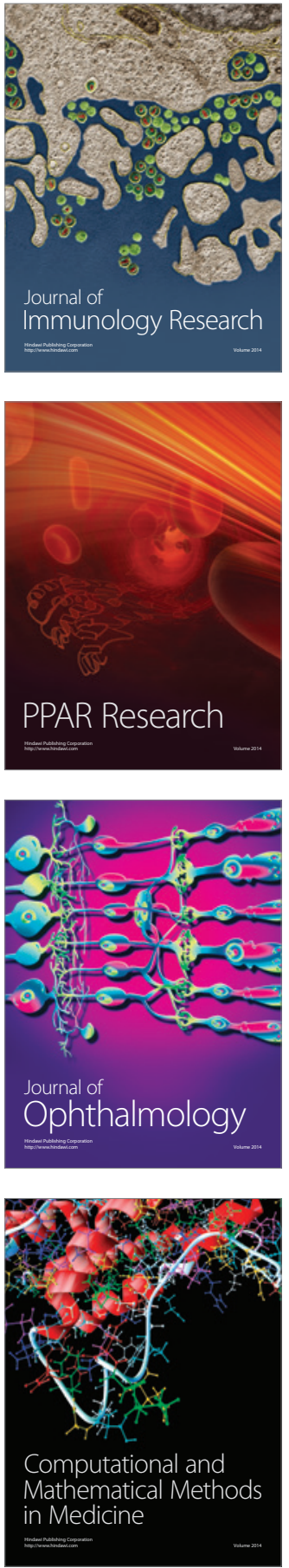

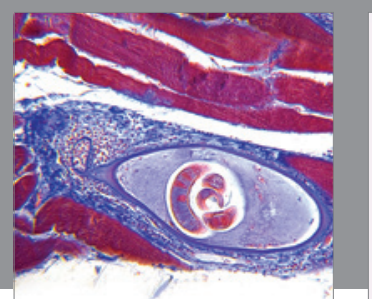

Gastroenterology Research and Practice

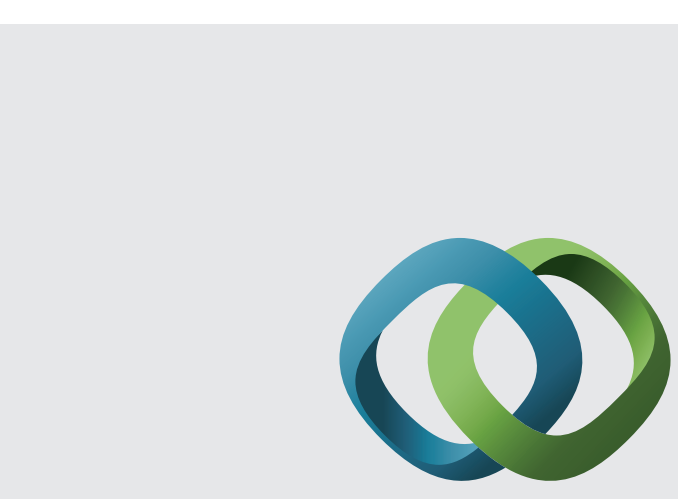

\section{Hindawi}

Submit your manuscripts at

http://www.hindawi.com
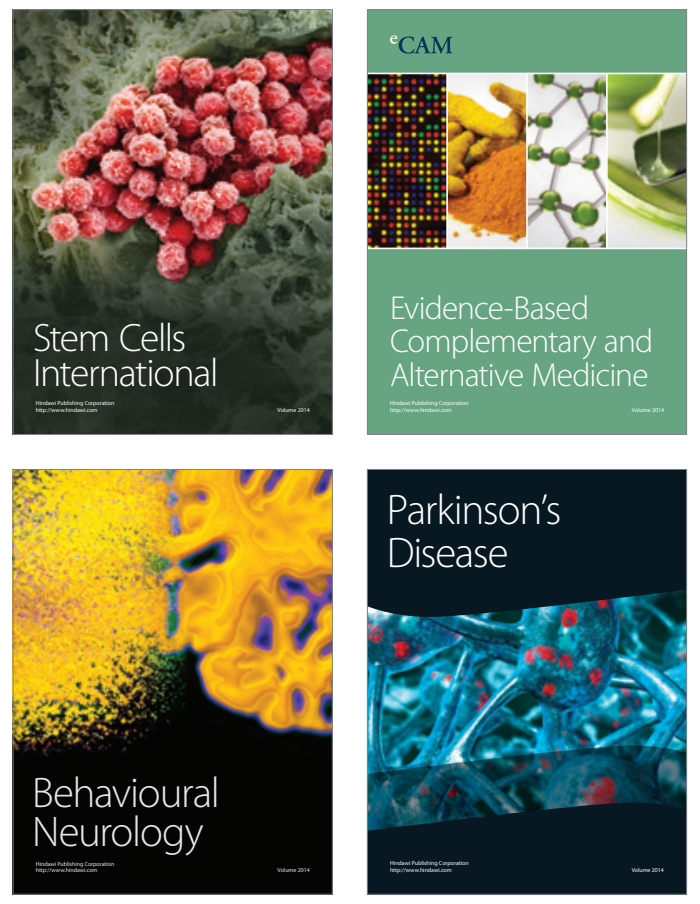
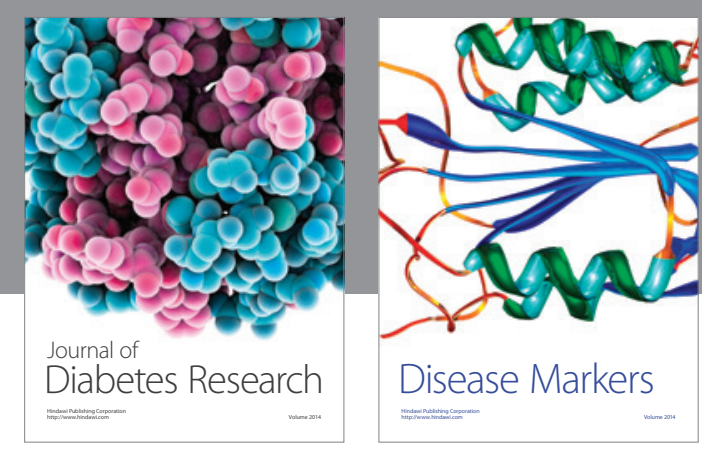

Disease Markers
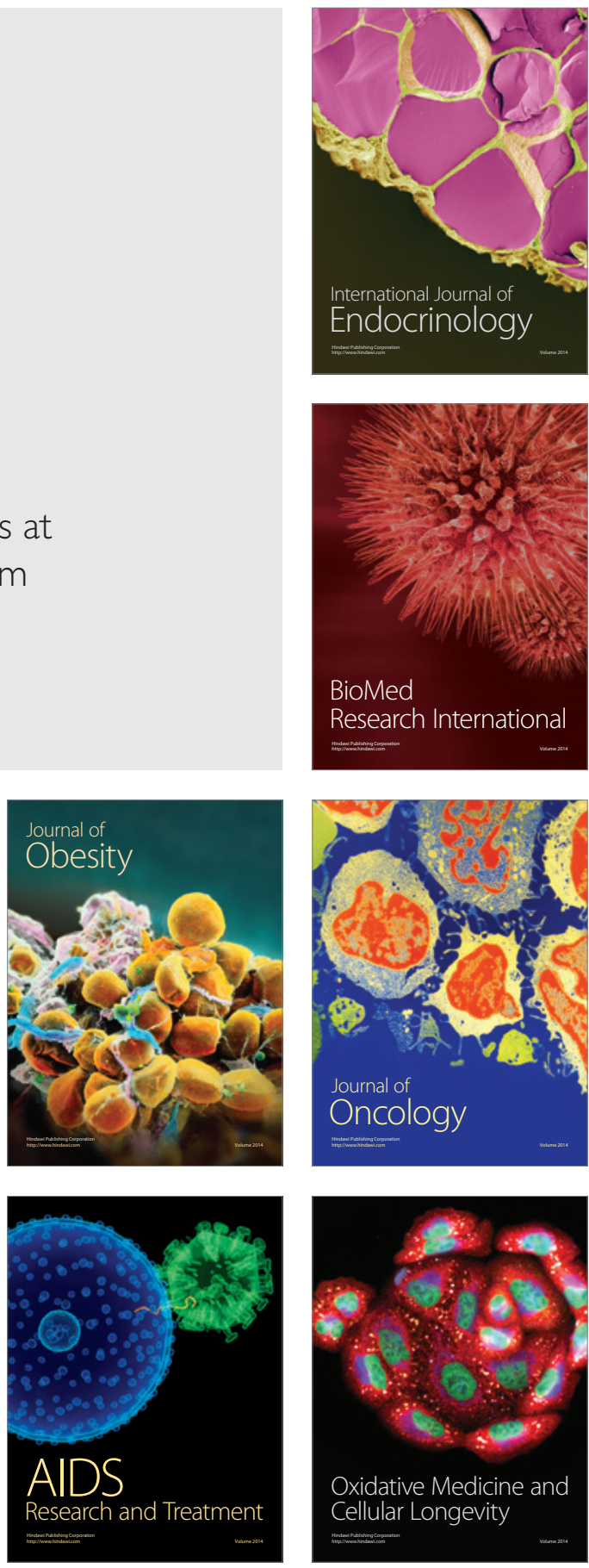